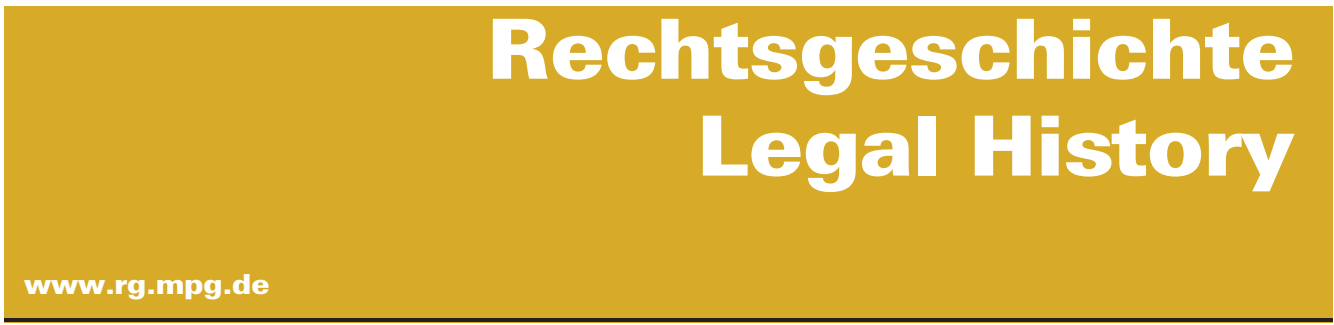

http://www.rg-rechtsgeschichte.de/rg22

$\operatorname{Rg} 222014$

$158-174$

Zitiervorschlag: Rechtsgeschichte - Legal History Rg 22 (2014)

http://dx.doi.org/10.12946/rg22/158-174

\title{
Li Xiuqing
}

The Chinese Repository and Chinese Criminal Law in the Minds of Westerners of the 19th Century 
Abstract

The Chinese Repository was the first well-established comprehensive English language journal in China. Based on the exploration of The Chinese Repository, the article provides a general view and an analysis of the contents concerning the Chinese criminal law and other relevant information published thereon, summarizing the views of Chinese criminal law held by the Westerners of the $19^{\text {th }}$ century and elaborating on the accountability and causes of the final consequence. Typical Westerners' views of Chinese criminal law were as follows: There are too many provisions on violent crimes, especially on homicides, and as for homicides, whether murders or manslaughters, a life for a life was always a principle to be followed and the perpetrator had to be executed, with only few exceptions to that rule. Since the purpose of criminal punishment was to penalize rather than correct or educate criminals, the punishments were severe and among them, capital punishment was widely employed to cruel effect. The abuse of extortion was widespread and unlawful extortion or torture was common though prohibited. Laws in China, including criminal laws, lacked certainty, which was not only due to the arbitrariness in lawmaking and law-amending, but also to the excessive degree of discretion conferred on local government officers and given to the practice of implication (Zhu Lian), which reveals a certain backwardness and cruelty. These nearly »backward and barbarian« or »bloody and cruel« views of Chinese criminal law, though somewhat correct, are partial and imaginary to certain extent. These views rooted in the minds of Westerners at that time partly owe to the language obstacles, partly to the influences of West-centrism, the ideology of racial superiority, and conflicts or different ideas between the Chinese and Western traditional or historical legal systems. The Chinese Repository was the main, though not the only, widespread media between China and the West, through which the Westerners' views of Chinese criminal law undoubtedly spread far and wide. 


\section{Li Xiuqing*}

\section{The Chinese Repository and Chinese Criminal Law in the Minds of Westerners of the $19^{\text {th }}$ Century}

Introduction

The Chinese Repository $(1832-1851)^{\mathbf{1}}$ is known for its important role in overseas Sinology and communication history between China and the West. It has been pointed out that »it shapes what China is for the Westerners of the $19^{\text {th }}$ century and it provides Western scholars with the basic literature of that period «. ${ }^{2}$ For mainland China, The Chinese Repository is mainly studied by the historians, and the recently-published articles like Study on the Introduction of Protestant Missionaries and Western Medicine Surgery - The Analysis of The Chinese Repository, ${ }^{3}$ E. C. Bridgman and The Chinese Repository, ${ }^{4}$ Interpretation of The Chinese Repository, ${ }^{5}$ have very high academic value. Professor Wu Yixiong's serial articles, including The Chinese Repository and the Study of Chinese History, The Chinese Repository and Chinese Language Study, and The Chinese Repository and Its Study on Chinese Social Belief and Customs, ${ }^{6}$ have analyzed this "database «, The Chinese Repository, from multiple vantage points, and delved deep into certain topics, many of which contain important academic values. The publication of fullest gravure of The Chinese Repository, will arouse more attention, and the research on it will be richer as a result.

As for the law circle, especially for those who study the legal history, they pay more and more attention to the modern history. The communication between China and the West, the conflicts between the Chinese law and the Western Law, the legal model adopted in the late Qing legal reformation, and the gains and losses for borrowing the Western laws to China have been hotspot issues. However, they seldom quoted The Chinese Repository, let alone the specific topics addressed in this masterpiece. So the study of The Chinese Repository from a legal history perspective is very important. Based on the half-a-year thorough study on Chinese law, especially the criminal content, the author is going to analyze the Chinese criminal law as perceived by Westerners at that time and its origins. If this article can help, then that will be the best reward for my efforts and research in these months.

\section{The Chinese Repository and Its Publication}

In order to illustrate the important role that The Chinese Repository plays in the study of overseas Sinology and the history of the communication between China and the West, and why the research of legal history, especially the modern legal history of China, should reference it, the foundation of this periodical, its life span and its key features of contents have to be explained.
* Doctor of Law at East China University of Political Science and Law; Professor at School of Law, East China University of Political Science and Law.

The first draft of this paper has been handed at "The Seminar of the $100^{\text {th }}$ anniversary of Chinese Penal Law Code - the second symposium on modern law « in HuaZhong University of Science and Technology in 2010. It was also delivered as a keynote speech. Professor Liu Guangan, Huang Jingjia, Chen Jingliang, Li Guilian, Qi Haibin, Yu Ronggen raised very good questions, and Professor Huang Yuansheng and Jérôme Bourgon encouraged me a lot. Moreover, Dr. Hu Zhen, Dr. Qu Wensheng, Ms. Zhang Yiran and other reviewers all gave me a lot of help and enlightenment. Accordingly, I would like to express my gratitude to them. The Chinese version was originally published in Journal for Legal History Studies, Taibei, 17 (2010) 219-253.

1 I would like to thank Dr. Wang Jie for his assistance in helping me to download from Google Scholar, he also helped copy The Chinese Repository in full. It can also be downloaded from http://www.archive.org. In 2008, Guangxi Normal University Press had already published The Chinese Repository in full collected by the library of Hong Kong Baptist University, and for convenience, it added Volume 21 Index based on the original 20 volumes. Simultaneously, it published a List of Articles and Subject Index of Chinese Repository, and this book's chief editor is Zhang Xiping, edited by Gu Jun and Yang Huiling. Definitely, it is good for scholars and researches.

2 HaO PING (2009) 4.

3 Ye Nong (2002).

4 Qiu Huafei (2006)

5 TAN SHulin (2008).

6 These three articles are separately published: Wu YIXIONG (2008a), (2008b) and (2009). 
The Chinese Repository (Zhong Guo Cong Bao) is the official translation of this periodical, it had been previously translated as Chinese Library or Chinese Periodical. It has ever been translated as Macao Monthly. ${ }^{7}$ Nowadays, it is commonly translated as "The Chinese Repository « by mainland academics. It was founded in Guangzhou in May 1832. The founder was the first US Missionary E. C. Bridgman (1801-1861).

The Chinese Repository is neither the first Western newspaper in China ${ }^{8}$ nor the first Americanfounded newspaper in China. ${ }^{9}$ But it is generally believed that it is the earliest English periodical published in modern China. ${ }^{\mathbf{1 0}}$ Founded in May 1832 and ended in December 1851, The Chinese Repository survived for 20 years. It was stable in terms volume and phase. A total of 20 volumes and 232 periods were produced. The volume use consecutive pagination in octavo format. The two largest volumes are volume 10 and 11 , both of which have 688 pages. The smallest one is volume 1, which has 512 pages. Moreover, the style of the publication is relatively fixed. The table of contents in volume 1 and 2 include Review, Miscellanies, Religious Intelligence, Literary Notices and Journal of Occurrences. From volume 3 to the last volume, under the premise that the table of contents outlined above is essentially constant, the book is arranged in the following order: Art. I, Art. II etc. The last article of each period is normally Journal of
Occurrences. The articles' length vary from each other, some up to dozens of pages, while some only a few lines. Leading articles are usually longer. The last one, Journal of Occurrences, mostly contains several brief messages. In addition, the extracts reproduced in the section are referenced, and each volume has an index. Given the fact that Chinese society was tumultuous at the time, and conflicts between China and outside world, including the first Opium War, it is rare for The Chinese Repository to maintain relative stability on its style when its publishing house moved from place to place on three occasions. ${ }^{11}$ And the journal deserves to be called a mature journal.

One of the clear purposes of The Chinese Repository was to illustrate the time and manner of the changes happening in China by commenting the foreign Sinology books which had already been published. By analyzing the authenticity of these books, the worthless and erroneous content of such books would be rendered obsolete, rendering republishing unnecessary. ${ }^{\mathbf{1 2}}$ In conformity with this purpose, The Chinese Repository seldom published articles related to the Western countries' systems, instead, the Chinese customs and its neighbours' customs were mainly focused on. As for its contents, the range of The Chinese Repository was very wide, including politics, history, geography, trade, economy, law, religion, natural history, language etc. So, for readers nowadays, The Chinese
7 Latourette (1963) 5, 86 (American).

8 The first modern newspaper published in China was Abelha da China on 12 September,1822, it was also the first foreigner-founded newspaper in China and the first Macao newspaper. It was published weekly and in Portuguese. It was shut down on 26 December 1823. Because of its short life span, its publications and influence are limited. The first English newspaper published in China was the Canton Register, it was founded by the British opium merchant James Matheson (1796-1878) in Guangzhou in 1827 as a commercial newspaper whose target audience were merchants and missionaries in China. See Gu Jun, YAng Huiling (eds.) (2008), "preface $\ll$.

9 The first American-founded newspaper in China was Chinese Courier and Canton Gazette, which was founded on 28 July 1831 . It was business- oriented and shut down in 1833. See note 8 .

10 Data shows that, in 1831, The Canton Miscellany published by the Eastern India Company in Guangzhou was suspended after its $5^{\text {th }}$ publication. Hereby, other statistics show that this magazine was only published in Macao, and its exact time was unknown (from www.publishing.com.hk and http://big5.china.com.cn/news). According to the author's reading experience, I prefer the former data, then the so-called »The Chinese Repository is the earliest English periodical published in modern China «, is yet to be proved. But one of the major reasons why there is such a saying is the short existence of The Canton Miscellany. When it was founded, its publishing company was in bad condition. After 2 years, that is in 1833, the British Parliament passed the bill to abolish the Eastern India Company's trade monopoly in China. So the trivial influence of this magazine has been neglected.

11 The Chinese Repository was founded in Guangzhou. Because the Imperial Envoy Lin Zexu ordered the expulsion of foreigners from China at that time, the publishing house moved to Macao in 1839, then to Hong Kong in October 1844, and finally back to Guangzhou in July 1845. Although based on the preface, Macao, the place of publishing, cannot be seen, the records can still be found in the $10^{\text {th }}$ period of Volume 13 and the $7^{\text {th }}$ period of Volume 14. See »Removal of the Office of the Chinese Repository to Hong Kong «, The Chinese Repository, Vol. 13, No. 10 (October 1844), p. 559; "Office of the Chinese Repository «, The Chinese Repository, Vol. 14, No. 7 (July 1845), pp. 351-352.

12 »Introduction", The Chinese Repository, Vol. I, No. 1 (May 1833), pp. 2-3. 
Repository can be called a comprehensive periodical. The attached list ${ }^{\mathbf{1 3}}$ showed that the editor put 1257 articles into 30 categories, the exact numbers are as follows: Geography, 63; Chinese Government and Politics, 81; Revenue, Army and Navy, 17; Chinese People, 47; Chinese History, 33; Natural History, 35; Arts, Science and Manufactures, 27; Travel, 27; Language, Literature etc., 94; Trade and Commerce, 60; Shipping, 26; Opium, 55; Canton and Foreign Factories, 36; Foreign Relations, 34; Relations with Great Britain, 38; Wars against Great Britain, 74; Hong Kong, 22; Relations with America, 21; Japan, Korea etc., 24; Siam and Cochinchina, 21; Other Asian Nations, 18; Indian Archipelago, 36; Paganism, 43; Missions, 102; Medical Missions, 48; Revision of the Bible, 40; Education Societies etc., 31; Religious, 29; Biographical Notices, 38; Miscellaneous, $37 .{ }^{14}$

After a thorough reading of these contents, the author believes that the religious contents were not the most important contents in The Chinese Repository, though it was founded by missionaries. They mainly focused on the introduction and reported on Chinese situations. As time passed by and China opened its doors to the outside world, more and more "authors" contributed to this periodical. Besides missionaries, diplomats, merchants, travellers and generals all delivered contributions. Hence, some scholars have pointed out that for 20 years in which The Chinese Repository was published, »the author's list is totally the list of British and American researchers who studied China that time«. ${ }^{\mathbf{1 5}}$ Apart from some specific topics, the Journal of Occurrences was mainly extracted from the Qing Government Gazette ${ }^{\mathbf{1 6}}$ and the Canton Register at that time. So the amount of reports on current events was considerable.

The Chinese Repository witnessed many historical events in modern China, including the deteriorat- ing relations between China and the West, the breaking out of the first Opium War, and the signature of unequal treaties between China and the West, from which the West's Consular Jurisdiction, along with other "privileges" were accepted by the Qing Government. For Western readers, it was the first China-oriented periodical, and every volume was published hundreds of times, even thousands of times. ${ }^{17}$ It was reprinted by major European periodicals, demonstrating its huge influence. Even nowadays, it is quoted in many articles, like Kenneth S. Latourette (1884-1968), a famous historian who was dedicated to the study of relations between China and the West, and Tyler Dennett (1883-1949) another well-known historian etc., they both quoted The Chinese Repository in their masterpieces, and paid high compliments to it. ${ }^{18}$

Therefore, as might have been expected, historians have been paying more and more attention to The Chinese Repository. Similarly, the study on the modern law, especially in the field of the SinoWest legal culture exchange history, should not be done without The Chinese Repository. To do otherwise would lead to an incomplete scholarly undertaking.

\section{The Chinese Criminal Law in The Chinese Repository}

The following section will analyse how The Chinese Repository published Chinese laws, especially criminal law.

According to the List, Law was not included in these thirty subjects, however, that does not mean that it did not publish any law-related content. In fact, in Chapter One, partial accounts from a report about the carrying out of capital punish-
13 "List of the Articles in the Volumes of the Chinese Repository, Arranged According to their Subjects «, The Chinese Repository, Vol. XX (1851), pp. ix-liv.

14 The exact distribution of these figures and categories can be found in LI XiUQing (2010b).

15 Gu Jun, YANg Huiling (eds.) (2008), "preface $\ll$.

16 As for the basic conditions of the Qing Government Gazette, and its contents quoted by The Chinese Repository, see Yin WENJUAN (2005).
17 There were 400 copies for the first and second volume. For the $3^{\text {rd }}$ volume, 800 copies, for the $4^{\text {th }}$ and $5^{\text {th }}$, 1000 copies. The exact publishing distributions are as follows: China, 200 copies; Manila, 15 copies; Hawaiian Islands, 13 copies; Singapore, 18 copies; Malacca, 6 copies; Penang, 6 copies; Batavia, 21 copies; Siam, 4 copies, New South Wales, Sydney, 6 copies; Burma, 3 copies; Bangladesh, Nepal, Assam, 7 copies; Ceylon, 2 copies; Mumbai, 11 copies; South
Africa, Cape Town, 4 copies; Hamburg, 5copies; Britain, 40 copies; America, 154 copies; there were 200 more copies delivered to European and American periodical offices and publishing houses. See »European Periodicals beyond the Ganges", The Chinese Repository, Vol. V, No. 4 (August 1836), pp. 159-160.

18 Gu Jun, Yang Huiling (eds.) (2008), "preface«; Dennett (1959) 580. 
ment and accusations were mentioned. In Chapter Five, it especially mentioned »in appropriate times, The Chinese Repository will publish all the important and worth-recording facts and stories, such as Chinese laws, education, customs, communications ...«. ${ }^{19}$ The »Execution of the Laws in China ${ }^{20}$ and "Homicides in China ${ }^{21}$ had already been published and "Ta Tsing Leub-le " ${ }^{22}$ had been published in three phases. "Notices of Modern China«, covered for four phases. The Chinese Repository also introduced "Characteristics, The Present Condition, and Policy, of the nation, the Penal Code , ${ }^{23}$ "Appeals from the inferior to the Superior Courts; Abuses in the Manner of Appeal; Accumulation of Cases in Provincial Courts; the Difficulty of Obtaining Redress «, ${ }^{24}$ »Courts of Justice, Judges, Clerks, Interpreters, Plaintiffs, Defendants, Prisons, the Number and Condition of Their Inmates ${ }^{25}$ and »Various Means and Modes of Punishments; Torture, Imprisonment, Flogging, Branding; Pillory; Banishment; and Death «. ${ }^{26}$ These Chinese law-related articles were all included in the Chinese Government and Politics, meanwhile, in the Chinese People, there were some other law-related articles.

In addition, both articles in this periodical and the List (including the General Index ${ }^{27}$ which was alphabetical) show that all the longer articles are contained in the List, while those "Journal of Occurrences" articles are not, perhaps since, according to the editor, they literally could not be called "Articles". Both these longer articles and »non-articles «, from the author's perspective, have law-related contents. Through analysis and law categories, we can divide this content as follows: The Legislation of China, The Implementation of Law, Criminal Law, Lawsuit, Prison, Land System etc. Lawsuit is the most complicated category among these, and criminal law is second to it. Land System and other Civil Law affairs are the most simple. In order to fit with the theme of this thesis, the following sections include Crime, Punishment, Inquisition by Torture and the Qing Legal Code and its Implementation.

\subsection{Crime}

In The Chinese Repository, there were long articles introducing crimes; moreover, they were introduced by specific reports. They mainly involved homicide, robbery, theft, arson, kidnapping, piracy, smuggling and adultery. Among these, homicide was most reported.

In particular, in one article by Robert Morrison (1782-1834) in which homicide was discussed, ${ }^{\mathbf{2 8}}$ the author's opinions could be seen as typical of Westerners' viewpoints in China at that time.

In China, since The Code of Tang, homicides were divided into six distinctions based on criminal's intentions, that were Mou Sha (more than two people planned to kill people, but under special circumstances, there could only be one
19 »European Periodicals beyond the Ganges«, The Chinese Repository, Vol. V, No. 4 (August 1836), p. 160.

20 "Execution of the Laws in China«, The Chinese Repository, Vol. II, No. 3 (July 1833), pp. 131-134.

21 "Homicides in China«, The Chinese Repository, Vol. III, No. 1 (May 1834), pp. 38-39.

22 "Ta Tsing Leuh-le«, The Chinese Repository, Vol. II, No. 1 (May 1833), pp. 10-19; Vol. II, No. 2 (June 1833), pp. 61-73; Vol. II, No. 3 (July 1833), pp. $97-111$

23 »Notices of Modern China: Introductory Remarks on the Characteristics, The Present Condition, and Policy, of the nation, the Penal Code«, The Chinese Repository, Vol. IV, No. 1 (May 1835), pp. 17-29.

24 »Notices of Modern China: Appeals from the inferior to the Superior
Courts; Abuses in the Manner of Appeal; Accumulation of Cases in Provincial Courts; the Difficulty of Obtaining Redress«, The Chinese Repository, Vol. IV, No. 6 (October 1835), pp. 262-268.

25 »Notices of Modern China: Courts of Justice, Judges, Clerks, Interpreters, Plaintiffs, Defendants, Prisons, the Number and Condition of Their Inmates«, The Chinese Repository, Vol. IV, No. 7 (November 1835), pp. 335-341.

$26 »$ Notices of Modern China: Various Means and Modes of Punishments; Torture, Imprisonment, Flogging, Branding; Pillory; Banishment; and Death «, The Chinese Repository, Vol. IV, No. 8 (December 1835), pp. 361-386.

27 "General Index«, The Chinese Repository, Vol. XX (1851), pp. lv-clxviii.
28 »Homicides in China: cases in which foreigners and natives are concerned, difficult to be adjusted; luh sha, or the six distinctions of homicide; exceptions occasioned by the rank and situation of natives; the usual exceptions not allowed to foreigners «, The Chinese Repository, Vol. III, No. 1 (May 1834), pp. 38-39. 
people), Gu Sha, (intentionally killing someone), Ou Sha (killing someone during a fight), Xi Sha, (treating murder as a game, the perpetrator had foreseen the result, but neglected to avoid it), Wu Sha (killing the wrong person), Guoshi Sha (manslaughter). Not only did Morrison notice these distinctions, he also wrote of their differences through detailed accounts of cases. He thought that though legal distinctions between different forms of homicide were made, capital punishment would be inevitable as long as people were killed, even in the case of manslaughter. This was unreasonable without doubt. The perpetrator caused deaths out of carelessness, rage, impulse, greed rather than out of intention, and for these coincidences, people were killed. In such instances the perpetrator deserved capital punishment, with the slight difference that it was carried out in a not so cruel way. Morrison also compared it with the British laws, and he pointed out that, in the same situation, British criminal law would allow the continuing of a perpetrator's life. He also believed that for all the civilized countries, their laws should be the protector of people's lives. People could not be killed effortlessly, out of a basic respect to human dignity, and this had been obeyed for a long time ago. However, in China, killing people was like owing debts, and the »debtor« had to pay the "creditor", and it was done through the death of the perpetrator, which was called »the blood pay for the blood «. It was a basic rule in Chinese law, which hardly had any exceptions.

There was another reason for Morrison's disgust for this rule, that was, the "pride and prejudice" between the Chinese and Westerners. Because of education and religious belief, there already existed difficulty in communication between the Chinese and Westerners, and this "pride and prejudice« had made it even worse. For the Chinese, foreigners were called »barbarians«. In cases involving foreigners, they could not avoid capital punishment if they had killed Chinese people, even it was just an accident (in practice, an array of foreigners charged belonged to this situation). So, the exception to this rule never applied to foreigners. All in all, foreigners' sentences were never commuted if they had killed another person.
Morrison pointed out, according to Chinese laws, punishment varied in homicide, and it largely depended on the status between two parties. Masters and slaves would deserve different punishment if they killed the other party. Furthermore, in normal cases, it was reasonable for a woman to kill a man who was trying to rape her, but if this man was her father-in-law, to whom she should pay respect and tribute, this woman would be killed if she killed her husband's father. And it was acceptable for a husband to kill his wife and her adulterer because of rage. Killing burglars would not deserve punishment. Reading between the lines of these descriptions of exceptions, it can be seen that instead of praising them for saving people's lives, Morrison was quite sarcastic. He called it »a glorious uncertainty«.

In addition, it is worth mentioning some reports related to homicides published in The Chinese Repository. One story was about the acquittal of a murder, ${ }^{29}$ to be more specific, he was honoured. In a village not far away from Guangzhou, Nanhai County, there was a notorious villain. He was ignorant of law and hurt many people, let alone the number of people who were insulted by him. One day, he conflicted with one villager because of business affair, by the same token, the villain humiliated this villager, whose son was angry and killed him with a knife. It was understandable that villagers cheered for him. The next day, the perpetrator turned himself in, and local officers dispatched people to investigate this case and reported this crime. In the end, this murder was acquitted and rewarded for killing this villain.

Another story was about decapitation of a son for the murder of his father. One day, a creditor came to the debtor's house and asked for money, he was very arrogant and humiliated this debtor, whose son was so angry that he threw a stone to the creditor standing near the door, unfortunately, the creditor dodged, instead, it hit the debtor's head, and he died on the spot. Because of what he did that led to his father's death, this unfortunate fellow was beheaded. The report especially mentioned that if he had killed his father deliberately, this boy would have deserved Ling Chi (which means death by the slow and painful process of 
being cut into pieces). From a legal perspective, this disparity between the various ways of carrying out capital punishment shows a certain degree of leniency towards manslaughter, but it was still very cruel. ${ }^{30}$

Here is a story about a woman killing her mother-in-law. She was first sentenced to Ling Chi, then, changed by the emperor, to beheading. A widow and her mother-in-law separately committed adultery with others to earn money. Because of the extenuating circumstances of the adulterer, the widow did not contact with him anymore. But her mother-in-law still asked her to haunt this individual to ask for money. Disobedient, the poor widow was always tortured by her mother-in-law. During one quarrel, this woman used knife to kill this old woman and threw her body into the river nearby. According to the provision of "killing father and mother-in-law«, the governor sentenced her to Ling Chi. Later, the supreme judicial office changed it to beheading. The editor finally commented that traditionally, Chinese women were like commodities for sale, they were always controlled by their parents, they performed prostitution and sexual acts and they were the accessories of fool and degradation. Hence, cultivating these people with pure spirit and avoiding degradation would be very important. ${ }^{31}$

One more case was that of a person who killed his grandmother and was put to death by villagers. "Among all the good virtues, filial piety comes first « is a popular saying in China, but some people could not perform that, and they even killed their seniorities. In late April 1848, in a village near Shanghai, there lived an elderly woman who was poor and had a few descendants. Unfortunately, her grandson was bad-tempered and was going to sell his wife. The elderly woman tried to stop this but was bullied to death by her grandson. In keeping with local customs, the elder woman's body was put in coffin and buried in the wilderness near the village. The villagers were supposed to send this villain to the local government, but they did not. After a discussion, they sent him to the coffin, tied his hand and buried him in the hole near the coffin, which had already been dug. They only allowed his head out of the earth. After one day, this individual perished. Sending this criminal to the government might have required money, and none of these villagers were willing to pay for it. Here, the case of the murder of a Chinese woman by her grandson encompassed a new homicide, which was the murder of a grandson by the neighbouring villagers. The magistrate did not intervene and nobody was charged, and the case was left unsettled. ${ }^{32}$

\subsection{Punishment}

When it comes to Chinese punishment, The Five Forms of Punishment would come to our minds first. The Five Forms of Punishment regulated the specific content and practical application of flogging, blows, captivity, banishment, death penalty. It is embodied in one article mentioned in the contemporary introduction of China, which covers "various means and modes of punishment; torture, imprisonment, flogging, branding, pillory, banishment, death «. Especially, there are numerous descriptions on the death penalty. The death penalty is divided into beheading and hanging. Neither of them is the same in cruelty. And there is no choice of application between these two. One example can be seen in a clause from the Qing Legal Code, Criminal Laws, Execution of a Sentence by a false Construction of the Laws: ${ }^{33}$ "If an offender who, conformably to the laws, ought to be strangled, is beheaded; or beheaded, when he ought to have been strangled; such deviation, if wilful, shall be punished with 60 blows; if committed by mistake, with 30 blows." This article also pointed out that both beheading and hanging are divided into summary execution and detention with reprieve.
30 »Decapitation of a Son for the Murder of his Father", The Chinese Repository, Vol. II, No. 9 (January1834), p. 432.

31 "Crimes and Punishment«, The Chinese Repository, Vol. II, No. 7 (November 1833), p. 336

32 "Statement Regarding the Murder of a Chinese Woman by her Grandson, and of the Murder of the Grandson by the Neighboring Villagers", The Chinese Repository, Vol. XVII, No. 9 (September 1848), pp. 480-481.

33 Quoted from the Qing Legal Code: Tian TaO, Zheng QIN (1999). 
Major criminal offenders should receive summary execution, while normal offenders should be detained with reprieve. A normal offender's death penalty should be judged after Autumn Assizes or Court Assizes. When it comes to the period of time when the implementation of death penalty was supposed to be banned, the article quoted the Qing Legal Code, General Law, the Five Forms of Punishment, Regulation which says »Punishment should be banned in January and June. A major criminal offender who ought to be summarily executed should instead be detained with reprieve. The death penalty should not be implied until the beginning of February or the fall. Punishment should also be banned at the turn of May and June, or in the event that autumn begins in June." Despite the writer having quoted this clause, he also admitted that he neither understood the legislative intent of this clause nor knew whether this clause was obeyed in every district. Meanwhile, he pointed out that he could not figure out the number of death sentences carried out each year in China because of the lack of knowledge. However, from the related situation written in the Qing Government Gazette and the Canton Register, there were many death penalties and cruel punishments in China. In the article, the writer also listed some information related to the death penalty which he was familiar with. Now they will be listed in sequence:

On 2 March 1817, 24 people were beheaded at the southern gate of Canton. Four days later, 18 people were beheaded. There were no reports as to their names or any other information on the executed. The government coldly reported the fact that they were executed and reported this case to the superiority. In October that year, the emperor signed 935 deaths warrants, Canton accounting for 133 of them. It was a considerable number, but only comprised a small proportion of the total number of executions that year.

On June 1817, out of rebellion to the emperor, two royalties were going to be executed by Ling Chi, through report to the emperor, the punishment was changed to hanging. The emperor also ordered the execution of these two people before the royal tomb to sooth the ancestors.

In 1819, a maniac in Henan killed his father and chopped him into pieces, and he was executed by Ling Chi. In Fujian, many peasants refused to pay for taxes, their leader was hanged and others received punishments too. On 16 December of that year, seven people were beheaded, however, their crimes were unknown.

In December 1822, in Huangpu, 10 people were beheaded because of robbery. One year ago in Chaozhou, several people died because they had committed robbery too.

In 1826, after the Autumn Assizes, 581 people were sentenced to death, among those, Canton accounted for 51, while Guangxi and Sichuan took up for 25 and 34 respectively.

On 14 November 1827, in Guangzhou, two rapists were beheaded in one day, along with 3 women, with their crimes unknown. On 19 December of that year, 7 people were beheaded because of piracy. Data shows 199 people received the same punishment that year, 135 of them were executed immediately, the rest of them were killed after the admission of the emperor; 3 of them were killed by Ling Chi, with their crimes unknown.

On 26 February 1828, 3 men were beheaded for murder and robbery; on $4 \mathrm{March}$, two pirates were beheaded. According to an official newspaper capital punishments were carried out almost every day that year, but the crimes were all obscure. In October, after the Autumn Assizes, the emperor signed 789 death warrants. Usually, the emperor would sign by distance, the furthest being places like Yunnan, Canton and Guangxi came first, usually in 40 days; the nearest province to the capital within 4 days. Normally, the emperor signed 90 to 100 death warrants every day.

In the autumn of 1829, the emperor signed 579 death warrants, 104 of which were carried out in Sichuan.

For local official newspapers, their reports on the death were minimalistic. They would just list the criminals who were murdered, without the crime committed or the number of those executed. Capital punishments are usually public and take place in a fixed location. Some cases were very ruthless and bloody. In one such case, the criminal was taken to the tomb of the victim, and his body was cut into bits and his heart was torn out as a sacrifice. For another, a 19-year-old woman was proved to have poisoned her mother-in-law, and she was executed by Ling Chi. Her husband was forced to see the whole process on the spot. Later, it was proven that he loved his wife more than his mother, and he received 50 blows and was imprisoned for one month.

The reason why the author explained the practical use of The Five Forms of Punishment was to 
illustrate the purpose of Chinese criminal law, that is, punishing rather than reforming and correcting. Apart from longer descriptions, the death penalties could usually be seen in Journal of Occurrences, they were the "favorites « by the editors. Decapitation and Ling Chi (death by the slow and painful process of being cut into pieces) can be seen through the work, which can be shown by the following examples, which are a small part of the total catalogued.

The Canton court circular announced the trial, which saw the sentencing and execution of 17 criminals. Their heads, severed from their bodies and put in small cages, were put on display in the market place, near the execution ground. Four days after the decapitation, their heads, still in cages, were labelled and sent off to Yinting (a town some miles distant from Canton as well as the native place of these criminals, and the scene of their depredations) to be exposed to the populace as well. ${ }^{34}$

On 4 August, 23 culprits were beheaded. This number of people did not result in any public disarray, even without compassion, which was surprising. ${ }^{35}$

In autumn this year, there were so many public executions. Yesterday, 24 people were executed in the execution ground. ${ }^{36}$

A robber was beheaded. On $11^{\text {th }}$ of this month, a notorious robber named Tsang was beheaded. Months ago, he was wanted by the government and was finally caught by a brave foreign navy lieutenant. In one hour, this criminal was convicted and executed. ${ }^{37}$

A 49-year-old man from Chaozhou was strangled for opening an opium store in Macao. In addition, an article was quoted from Canton Press in which a witness described the process of execution especially. ${ }^{38}$
Decapitation in Canton and hanging in Hong Kong have attracted attention this month. The first on account of the great numbers and frequency, and the latter for the short period, 60.5 hours, between the passing and execution of the sentence, on two malefactors, one a Chinese and the other an Englishman. In Canton, more than 20 people, some of them women, were decapitated in one day. Here, as was common practice, the criminals were adjudged in the morning and then led away to the potters field, where they were decapitated on the same day. ${ }^{39}$

Last year, in Canton, 1,200 criminals were decapitated, thousands of criminals have been imprisoned. ${ }^{40}$

This report especially mentioned that because the victim was British, the government invited a few English soldiers to watch the execution. ${ }^{\mathbf{4 1}}$

A late robbery committed in Canton. On the $6^{\text {th }}$ night of April, beyond the Western gate, one pawnbroker's shop was attacked by a band of robbers. The gang of some 300 people plundered more than 3,000 taels of silver. On 4 May, 8 of the culprits were decapitated. Two days later, five more of the gang were arrested and delivered up. They were beaten ( 1000 blows) with the rattan out of the gate of the pawnbroker's shop. They were moreover beaten some tens of blows with a cudgel until they were half dead. On the $7^{\text {th }}$, four more of the culprits were delivered up and these were hacked to death with a knife. On the $8^{\text {th }}$ day, three more of the culprits were arrested and brought in, and they were burnt to death by fire. ${ }^{\mathbf{4 2}}$

Most of death reports from The Chinese Repository did not have comments. The execution time and place, the number of criminals killed and which execution was applied were mentioned in the report. It seemed that they were daily occurrences. But from a few reports with comments, we
34 »Decapitation «, The Chinese Repository, Vol. I, No. 2 (June 1832), p. 80.

35 »Execution ", The Chinese Repository, Vol. II, No. 4 (August 1833), p. 192.

36 »Public Execution, Monday, 7 December, The Chinese Repository, Vol. IV, No. 8 (December 1835), p. 391.

37 "A Notorious Robber", The Chinese Repository, Vol.VI, No. 9 (January 1838), p. 448.

38 "A case of Strangulation ", The Chinese Repository, Vol.VI, No. 12 (April 1838), p. 391.
39 "Public Executions «, The Chinese Repository, Vol. XIV, No. 7 (July 1845), p. 352.

40 "Decapitation of Criminals«, The Chinese Repository, Vol. XVI, No. 3 (March1847), p. 151.

41 "Execution of Murderers«, The Chinese Repository, Vol. XVII, No. 1 (January, 1848), p. 54.

42 "Robbery and Executions«, The Chinese Repository, Vol. XVII, No. 6 (June 1848), p. 320. 
could see that the editors were obsessed with reporting these things, showing aversions towards the frequency and numbers of executions in China, along with the cruelty of public executions and the purpose of criminal laws, which was punishing rather than correcting and reforming. They also criticized the public for their indifference to the execution of death penalty.

For example, the report of the Vol. 1, No. 7: On the $22^{\text {nd }}$ instance, seven men, on 25 November, several more were beheaded, at the usual place of execution in Canton. (In a former number we mentioned the decapitation of 17 individuals.) To which the editor commented: »These executions were performed in the most public manner, and are of very frequent occurrence, amounting to many hundreds and some say from one to two thousand annually, they are noticed, in the court circular, in the most summary manner. Without even mentioning the names or the number of criminals, it simply stated: the execution of criminals was completed. [...] such gross exhibitions of cruelty, so frequently presented, not only shock the better feelings of human heart, but tend to render the hardened more hard, and the desperate and cruel still ferocious. Especially must this be the case, when there is but little moral feeling, and when there is no fear of omniscience, nor apprehension of a just retribution in a future state of being. [...] Alas! There is no knowledge of God; no love to his name; no fear of his wrath to this land.« Finally, they would be the sacrifice of the paternal law. ${ }^{43}$

In the report of Vol. 18, No. 6, we read: »The number of executions during the present month has been 28, nearly equaling those of last month «; the editor added »and if the present administration long continues in power, the people of the two Kwang provinces will long remember its bloody rule. One case of judicial murder has excited not a little mark among the people, and is in fact such an atrocious deed as might naturally arouse indigna- tion.« In addition, the editor mentioned that a scholar named Li was arrested and executed because of his provoking words, and the governor even "mandated to the people not to listen to such specious words, lest they be involved in a like dreadful end." 4

One more example: »The executions of Chinese «, from Vol. 19, No. 1. A general report mentioned that every year hundreds of people were executed in Guangzhou, but because of the governor's laziness, the exact number of people killed was unknown. These criminals were often executed in a fixed place, some people calling it "a public square", and for the time without executions, it was occupied by potters, so it had a nickname called »a potter's field «. Here, 20 people were beheaded several days ago, then, the editor outlined the details. ${ }^{45} \mathrm{He}$ mentioned that when the officer supervising the execution left, people rushed to see torn bodies and blood. He commented that it was surprising to see Chinese's indifference to life. Apparently, this way of execution did not perform its reforming function in fact. ${ }^{46}$

\subsection{Inquisition by Torture}

Strictly speaking, inquisition by torture belongs to the department of Criminal Procedure Law, but it has close relations to accurate sentencing and convicting. Inquisition by torture, having existed since ancient times, was applied both in China and abroad. In China, it was regarded as an important measure of getting truth and evidence, rather than punishing. But since the Qin Dynasty, it had no longer been considered as a good method, on the contrary, those who abused inquisition by torture, in return, would be blamed and punished. In each dynasty, there were many provisions in the Code regulating it. The Qing Legal Code . Criminal Laws, Imprisonment of, and Procedure Against Unaccused and Unimplicated Persons said: "All officers of government, and their official attendants, who, insti-
43 »Decapitation«, The Chinese Reposito$r y$, Vol. I, No. 7 (November 1832), pp. 291-292.

44 »The Number of Executions", The Chinese Repository, Vol. XVIII, No. 6 (June 1849), p. 336.

45 During this same period, the record of executions could be seen in some foreigners' notes and essays. See Hunter (2003) 169-170 and SMITH
(2007) 92. Its quote especially mentioned that "a potter's field « was a pun, it derived from the Bible. As for its disparity with the execution of European counterpart, Professor Jérôme Bourgon had novel ideas. See Bourgon (2006).

46 »Executions among the Chinese«, The Chinese Repository, Vol. XIX, No.1 (January 1850), p. 55. 
gated by private malice and revenge, designedly commit to imprison an unaccused and unimplicated individual, shall be punished with 80 blows." Furthermore, it regulated: »the inspectors and governors of prisons, their official attendants, and the jailors, when privy to, and not giving information against, such illegal proceedings, shall be liable to same punishments, except in capital cases, when a mitigation of one degree shall take place.« And "all officers of government, and their official attendants, who, instigated by private malice and revenge, designedly examine with judicial severities any unaccused and unimplicated person, shall, although they should not so by doing actually wound such person, be punished with 80 blows." Also, the instrument of inquisition should be lawful, which should obey the Qing Legal Code, General Laws.

But in real practice, lots of magistrates employed inquisition by torturing. The Chinese Repository had quoted many articles from the Qing Government Gazette and the Canton Register, along with The Indo-Chinese Gleaner ${ }^{47}$ to report this phenomenon: A report of the Qing Government Gazette (1817.8.9) showed many local magistrates had abused inquisition by torture (on innocent people) and were bribed. The Qing Government Gazette (1818.1) showed two people died of torture. The Indo-Chinese Gleaner (1819.7) reported a supervisor once told the emperor, »in Sichuan, many people died of painful inquisition«. He also said, "local magistrates hoped those who would be killed through the regulations of laws were killed during the inquisition, saving their efforts to giving them to superior courts«. The Indo-Chinese Gleaner (1821.5) reported a real murderer was found after five to six years, but during this time, more than fifty people had been tortured by inquisition. The Canton Register (1820.7) reported a magistrate in Anhui was accused of torturing suspects, he nailed the palm of one suspect, out of pain, the poor fellow struggled and tore his palm free, then upon being nailed again, eventually died.
This magistrate also subjected suspects to other extreme forms of torture. Finally, he was acquitted by the emperor. In addition, the Canton Register (1829.7.16, 9.2, 10.3, 12.12, 1830.7.3) published reports on death caused by inquisition by torture. ${ }^{48}$

So many cases related to inquisition by torture are used to illustrate an author's viewpoint, that is, though inquisition by torture existed in many countries at the time, China took centre stage. The authenticity of this viewpoint remains to be proven maybe, but it is true that the practical application of this inquisition was not effective. In 1799, the Emperor Jia Qing announced an imperial decree to use standard instruments during an inquisition, and that whoever used their ownmade tools shall be punished severely. In 1810 and 1812, he again gave similar orders. But even under the reign of Emperor Dao Guang, the abuse of inquisition by torture was still rampant, and magistrates even used this to blackmail money and dispatched captors even to rob money, frightening people a lot. In 1827 , only in the province Zhili, 23,921 officers were dismissed. ${ }^{49}$

\subsection{The Qing Legal Code and its Implementation}

The Qing Legal Code and its implementation need to be analyzed when speaking of the criminal law in The Chinese Repository.

George Leonard Staunton (1737-1801) was named Secretary to the British Mission to the Chinese Imperial Court, and his son, George Thomas Staunton (1781-1859) came along with him. George Staunton exerted a huge influence in SinoBritish relations, and in 1810, he translated $» T a$ Tsing Leub-le« (»Ta Tsing Leu Lee«, the English version of the Qing Legal Code), which was the first work translated directly from Chinese to English, becoming the major basis for Westerners to judge Chinese laws. The evaluation of the Qing Legal Code by The Chinese Repository can be seen from the previously-introduced articles: "Ta Tsing Leub-le»
47 See Memorials of Protestant Missionaries to the Chinese (2002).

48 "Notices of modern China: various means and modes of punishment, torture, imprisonment, flogging, branding, pillory, banishment, and death «, The Chinese Repository, Vol. IV, No. 8 (December 1835), pp. 361-386.
49 "Notices of modern China; officers of the inferior magistracy and police; domestics of the principal officers; malversations of the police; extortions and cruelties of inferior officers«, The Chinese Repository, Vol. IV, No. 5 (September 1835), pp. 214-229. 
and "Characteristics, The Present Condition, and Policy, of the Nation, the Penal Code" from "Notices of Modern China: Introductory Remarks«. It can be deduced from the Index that the former one was written by Bridgman, while the latter was from R. Inglis.

Based on Staunton's version, Bridgman firstly introduced the history of the Qing Legal Code. Then he presented it in seven parts, that is, general laws, civil law, fiscal law, ritual laws, military laws, criminal laws and laws relative to public works. Finally, he drew the conclusion that the Qing Legal Code was a valuable work for aiding people's understanding of the Chinese customs. And Chinese laws relied on the emperor's ideas. For old customs, their authenticities were decided by the emperor's preferences. In general, most of provisions from the Qing Legal Code were good, with many dissenters, however. It would be very interesting to compare these provisions with those of ancient or modern ones from Western countries. As flawed as Chinese laws may have been in Westerners' eyes, they were highly regarded by the native Chinese. They were expected to be enforced to the letter and to be stable. ${ }^{50}$

Like Bridgman, Inglis started introducing the history of the Qing Legal Code first. In addition, he began to focus on several revisions of Ta Tsing Leu Lee since the publication of the English version. Since 1746, it was regulated that "small revision for provisions in 5 years, substantial revision for provisions in 10 years«. For Ta Tsing Leu Lee, its additional clauses were added or reduced even though its main structure remained stable. Inglis mentioned the change for Ta Tsing Leu Lee in 1830 and pointed out the randomness of Emperor Dao Guang in revising the laws.

In contrast to from Bridgman, Inglis combined specific provisions with juridical practice to illustrate that some clauses lacked both certainty and practical effectiveness. For example, the »defining crimes without provisions « in the Qing Legal Code, general laws regulated: when there is no provisions defining certain crimes, other related provisions should be quoted. Based on similar clauses, magistrates can define certain crimes, adding or reducing punishment. If they judge crimes without similar clauses, they would be charged with negligence. From Inglis' point of view, this way of judging crimes had the same problem with Roman Empire in Commentaries of the Laws of England by William Blackstone: »Judge's discretion might lead to unjust and suppression." Similarly, in the Qing Legal Code, Criminal Laws CCCLXXXVI regulated: "whoever is guilty of improper conduct, and such as is contrary to the spirit of the laws, though not a breach of a specific article, shall be punished, at the least, with 40 blows, and when the impropriety is of a ferocious nature, with 80 blows «. This set leeway for the judges, illustrating the randomness of law. Inglis also pointed out that it was ubiquitous to see magistrate violating laws, and for some, even fabricating clauses. Furthermore, in some villages, there were many customs held by elderly people. They compelled people to obey these customs, whether legal or not, and the officers strongly supported them.

In addition, Inglis criticized the system of Zhu Lian (implications of other innocent people). He thought that the civilized Qing Legal Code showed was just as Visigoth's. But for Visigoths, perpetrators' family members or relatives would not be involved, which was different from Zhu Lian in China. The Murder of Three or More Persons in One Family of the Qing Legal Code, Criminal Laws CCLXXXVII regulated: "Any person who is guilty of killing, by previous contrivance, intentionally but without premeditation, or in the court of a robbery or house burning three or more persons, whereof none were guilty of capital offences, and all of them were relations in the first degree, or inmates of one family; and also any person who is guilty of mangling and dividing the limbs, and thus in a cruel and revengeful manner killing any individual, shall, when convicted of being a principal offender, suffer death by a slow and painful execution. The property of such principal offender shall be forfeited to the use of the suffering family,
50 The last sentence, actually, was from "Introduction« of Ta Tsing Leu Lee, by Staunton. He also added after this sentence, »On the contrary, Chinese laws are usually distorted by potentates and supervisors. Unfortunately, it would not cause problems. For the degree of its severity and comparison with other nations', the only thing can be done is our estimation. But something seen is really helpful to China, and it has evidence, that is, unlawful and notorious deeds would never escape punishment, whatever the perpetrators are.« These positive remarks were omitted by Bridgman when he quoted from Staunton, which were worth ruminating. See Staunton (1810), Introduction, xxviii. 
and his wife and children shall be banished perputally to the distance of 2000 lee.« Inglis also mentioned in 1832 that the Board of Punishments used to propose the revision of the Qing Legal Code, Criminal Laws, for the range of Zhu Lian was so wide, however, that they were rejected by the emperor.

The application of laws in China can be seen in an article entitled "Executions of the Laws in China ${ }^{51}$ It was written in the form of letter from readers, asking (to be specific, condemning) the authenticity of the execution of laws in real practice. According to Index, the author was Morrison. His main point was that as organized as some clauses were, they did not function in real practice. In addition, he also listed a few examples as well as commented on the fact that the idea of »common law» and »lex non scripta« was not accepted in China, but magistrates usually used previous habits in judging a case, which was contrary to clauses in the Code, implying their disregard of the law.

3 Chinese Criminal Law in the Minds of Westerners Based on The Chinese Repository

The basic characteristics of Chinese criminal law from The Chinese Repository can be seen through my previous analysis. The following can be regarded as the Chinese criminal law in the minds of Westerners of that time.

First, it is about the violent crimes, among these, homicides take the lion's share. Murder or manslaughter, as long as death was caused, the perpetrator would be killed, that was from the Chinese entrenched belief in »life for life«. It was a basic rule, though it had exceptions, which only the Chinese could enjoy. For foreigners, death would be inevitable as long as death happened, even if it was just a mere accident. Some exceptions for the Chinese could be seen from the different punishments applied to the same crime, which depended on the status between the criminal and victim and their ages. Typical examples were masters killing slaves and husbands killing his wife and adulterers etc.

Second, it is about the cruel punishments. Flogging, branding, pillory and other punishments were quite bloody. They were further illustrated by the widespread usage of the death penalty and its ruthless execution. Every year, a considerable number of people were executed by capital punishment, but the governmental gazette only touched this topic slightly. Hanging could be called mercy, most criminals were decapitated; in some instances Ling Chi might be applied as well as Xiao Shou (head cut off and hung at a higher place on public display). The death penalty was carried out publicly, and sometimes, the relatives of the executed had to see this bloody execution. Execution could also be held in front of the victim's tomb, and it was taken as a sacrifice. Citizens were generally indifferent to the cases themselves, with the exception of the carrying out of the death penalty in public, which they found quite interesting. Barbarian is the punishment, backward is the belief. All in all, Chinese criminal punishment only focused on punishing people rather than correcting and reforming them.

Third, it is the abuse of inquisition by torture. Inquisition by torture was supposed to be a method for obtaining the truth and evidence rather than a mere punishment of the criminal. Ancient Chinese laws permitted inquisition by torture, though with restrictions. The abuse of it could hardly be constrained, and the unjust cases and the numbers of people who died because of the torture were considerable. This also revealed the barbarity of the criminal law.

Fourth, it is the arbitrariness of the ancient Chinese law, including ancient criminal law. Legislation and revision of laws were random, and »defining crimes without provisions « was the worst case of interpreting law, which gave the judge maximum discretion. Certain provisions could even be distorted by the misinterpretation of judges. They profaned laws for their own profit, and sometimes judged the case by way of local customs. Furthermore, the practice of implication (Zhu Lian) had been interpreted since ancient times, which highlighted the backwardness of belief and the brutality of punishment.

All in all, the ancient Chinese criminal law on The Chinese Repository was almost good for nothing. In a nutshell, it was »backward and barbarian «, »bloody and cruel «. But from the early $19^{\text {th }}$ century when George Thomas Staunton translated »Ta

51 "Executions of the Laws in China",

The Chinese Repository, Vol. II, No. 3

(July 1833), pp. 131-134. 
Tsing Leuh-le«, he made considerable tributes, and his father George Leonard Staunton, who had received an honorary doctorate degree in law at Oxford University, made many positive comments on Chinese criminal law, ${ }^{52}$ along with William Miller, who both praised and criticized the Chinese criminal law in his book The Punishments of Chi$n a ;{ }^{53}$ it could be deduced that Chinese criminal law received worsening comments.

The first question is whether their opinion of ancient Chinese criminal Law belong to "Collective Imagination«. Edward Wadie Said had a wide influence over Western Orientalism. He believed that the Western Orientalism came into being with the expansion of imperialism abroad. Influenced by Western cultures, it »didn't share the objectiveness we imagined «. It was totally »Collective Imagination «.

In reporting other Chinese aspects, The Chinese Repository did make some mistakes. For example, „Yi Mu« (meaning the chief of foreigners) was translated as »the barbarian eye $« .{ }^{54}$ In commenting on History of the Three Kingdoms, it felt like the author mistook it with The Romance of Three Kingdoms. ${ }^{55}$ For Dream in the Red Chamber, the author could not tell the sex of Jia Baoyu. ${ }^{56}$ In the first commentary Statistical Notices of the Ocean Kingdom with Maps, the author defined Lin Zexu as the writer of this book, ${ }^{57}$ fortunately, he corrected his mistake later. ${ }^{58}$ For cross-culture and cross-language reading, mistakes are unavoidable. For the people of that time, it was difficult to master Cantonese, Mandarin and English at the same time. However, these glaring mistakes made people doubt the level of Chinese of these authors who wrote for The Chinese Repository. In fact, even Bridgman, the founder and main writer for The Chinese Repository, poorly translated the negotiation and signature of the Treaty of Wanghia, when he had already been in China for more than a decade. His translation was occasionally better than the average Americans', however the treaty he translated was "obscure «. ${ }^{59}$ Indeed, during the negotiation of the treaty, the argument surrounding word selection for the translation even superseded arguments pertaining to opium trade. So, it could be seen that The Chinese Repository did not fully exercise its founding purpose, which was to introduce what true China was. But we could not completely deny its authenticity, for most of its reports had original sources, like the sources from the Qing Government Gazette or other official governmental reports. At the same time, it spun fallacies, for homicides, it believed that whether manslaughter or murder would all be killed, and it was not true. ${ }^{60}$ Therefore, the ancient Chinese criminal law it depicted had some authenticity, whilst having imaginary factors.

The following question is whether the Chinese criminal minds in The Chinese Repository were ideological. Its founders and editors were missionaries, and so were its main authors. Despite the fact that most of its content was non-religious and more different identities later came to this periodical, all of them had nonetheless grown up in the Christian culture specific to Western society. Chi-
52 For example, he especially mentioned »all the death penalties were executed at the same time, with no maximum than 200 people each time. For a country enjoying such a huge population, this amount was very little ... for the degree of punishment, it was not severe, meaning not many people committed crimes «. STAunton (1997) 479.

53 As for the perspective of MILLER (1801), it could be found in Contact and Confrontation (2007) 114-117.

54 »Edicts from the Governor and Hoppo of Canton«, The Chinese Repository, Vol. III, No. 4 (August 1834), p. 188 . The reading of the influence of this misinterpretation and its influence can be seen in LiU He (2009) 64-73.
55 »Notice of the San Kwo Che, or History of the Three Kingdoms", The Chinese Repository, Vol. VII, No. 5 (September 1838), pp. 233-249.

56 »Hung Lau Mung, or Dreams in the Red Chamber«, The Chinese Repository, Vol. XI, No. 5 (May 1842), pp. 266-273.

57 »Hai Kwoh Tu Chi, Statistical Notices of the Ocean Kingdom with Maps, in Fifty Books", The Chinese Repository, Vol. XVI, No. 9 (September 1847), pp. 417-424.

58 "Japan: a translation of the $12^{\text {th }}$ chapter of the Hai-kwoh tu chi, or notices of foreign countries, illustrated with maps and engravings, published at the city of Yang Chau fu in Kiangsu, in the summer of 1847 «, The Chinese Repository, Vol. XIX, No. 3 (March 1850), p. 135.
59 See Lazich (2008) 198.

60 In Qing Dynasty, Xi Sha (took murder as a game, the perpetrator had foreseen the result, but neglected it), Wu Sha (killed the wrong person), Guoshi Sha (manslaughter) deserved lighter punishment than Mou Sha (more than two people planned to kill people, under special circumstances, there could only be one person) and $\mathrm{Gu}$ Sha (intentionally killing someone). Cases can be seen in Xu Lian, XIONG E (2009) 164-165. It can also be seen in QUAN SHICHAO, ZHANG DaOyuAN (2009), Taken from Chapter 13 to Chapter 17. 
na, for them, was »the other «. When China and the West's relations worsened, which even resulted in war, these people would have had a sense of superiority when looking at this feeble empire; their divergence from Chinese beliefs was inevitable. ${ }^{61}$

Bridgman used to depict the Chinese as »arrogant, deceitful, telling lies, lack of love for nature, theft, robbery, murder etc.", and it "came from their hearts and could be seen everywhere«. Furthermore, "they did not restrain them, instead, cherished and connived at them «. ${ }^{\mathbf{6 2}}$

Similarly, after having lived in China for more than 10 years, in 1824 Morrison said the following of his work: ${ }^{63}$

»Although the Chinese had rich literature and arts, they were still absentminded idolatries. They worshipped things created, not the one who created them. They hated God, and they were full of injustice, evil and obsession with idols. Though China had its own civilization, the Chinese were still jealous, deceitful and the tellers of lies. They had metaphysical views and they were selfish, greedy, shrewd and indifferent. As mentioned, these were typical traits of the Chinese."

For the chief editor and main author for the last three years of The Chinese Repository, S. W. Williams, who was called »the best sinologist in America«, his remarks on China could be lavish. He called China »the highest civilized nation among pagan countries«. However, he was unable to exempt himself from »conventions«. In 23 August 1847, he expressed the same viewpoint as Morrison in his letter to his fiancé. When describing his motivation for publishing The Middle Kingdom, he said: ${ }^{64}$

»I think my motivation for writing a book about China is right. One of my motivations is to let my Quakers know more about Chinese destiny. I want to let people know that we should preach to Chinese of our dogmas. Now the Chinese politics is increasingly chaotic, opium and moral decay are undermining this country. Only gospel can save them. There may be many reasons for causing their indifference, but their ignorance must be the main reason. Getting rid of ignorance, to a huge extent, can save this people from decay.«

West-centrism and national superiority make The Chinese Repository one-sided. Its editors and authors quoted the reports from the Qing Government Gazette based on their own preferences, sometimes, intentionally, focused on the barbarian and brutal aspects of Chinese criminal law, that is to say, they were quite interested in the dark side of it. Speaking of the reason why they chose to do so, it had something to do with their founding purposes: arouse attention and help from the Western societies who were more legally civilized following the law reform of the $19^{\text {th }}$ century by listing the severe problems of China and its law, including Chinese criminal law. ${ }^{65}$ Hence, the theory of Edward Wadie Said mentioned before serves as a
61 The reason for the worsening comments on Chinese from Westerners after the mid $18^{\text {th }}$ century can be seen in Blue (2005).

62 »Universal Peace; obstacles to it in the character and government of nations, particularly of China and Japan; with remarks on the means best fitted to remove these obstacles«, The Chinese Repository, Vol. III, No. 11 (March $1835)$, p. 257.

63 Morrison (2004) 234.

64 Williams (2004) 86.

65 Once upon a time, whether in Europe and US, public executions, dumping bodies on the street, tearing a person asunder and inquisition by torture were very popular. In 1787 , Benjamin Rush (1745-1813), one of the foun- ding fathers of America who signed The Declaration of Independence, said in the »Society for promoting political inquiries«: I cannot help entertaining a hope that the time is not very distant when the gallows, the pillory, the stocks, the whipping-post, and the wheel-barrow (the usual engines of public punishments) will be connected with the history of the tack and the stake as marks of the barbarity of ages and countries and as melancholy proofs of the feeble operation of reason and religion upon the human mind. From the late $18^{\text {th }}$ to the early $19^{\text {th }}$ century, with the emergence of new laws and criminal theories, Western countries abolished old laws and old customs one after another, the punishment of pillory was abolished in France in 1789, and for Britain in 1837. By 1840, ruthless punishments like public execution had almost vanished. Though the process was not smooth, for the most part from 1830 to 1840 when The Chinese Repository was founded, punishment had been transformed from a intolerable treatment to a mechanism which temporarily deprived rights. And this theory came into existence in Western countries. Those punishments which were called »the marks of the barbarity of ages and countries « by Benjamin Rush were strongly restrained, though not completely vanished. See Foucault (2007) 7-17. 
cautionary tale, even though there are contentions of his viewpoints. Moreover, in modern Western literature, opinions exist for introspecting, which is the superiority in studying the Chinese law history. Forty years ago, an American scholar, David C. Buxbaum reminded his fellows in his article: ${ }^{\mathbf{6}}$

»Our viewpoints on the practical function of Chinese laws are rooted in the 19-century-reports by the racists who were western diplomatic personnel, clergymen and merchants. They thought they were spreading civilizations like western commodities, politics, laws and religions to barbarians. In fact, many researches on Chinese laws were not lucubrated. Instead, they were reiterating the slogan from their fellows and friends who were >Pro-West, AntiChinar.»

Last but not least, there is another question. Apart from ideology and language, are there any other factors leading to the misinterpretation and imagination of Chinese laws? The answer is yes. Among these factors, the fact that Westerners could not understand the Chinese legal perspective is paramount.

Many classic works on the comparison between Chinese and Western legal perspectives can be found in China nowadays, and British S. v.d. Sprenkel also makes for a reasonable read. Several of his comments need highlighting. Firstly, the Qing Legal Code, though criticized, received praise for its straightness and clearness when the English version was first published. In fact, law-makers were trying to contain all accidents and crimes that might happen in the future when establishing this Code. Thus, ambiguity would be unavoidable because they could not foresee future, and certain acts might not be defined so specifically, creating a lot of trouble for those who had to interpret them. And the Qing Legal Code outlined detailed regulations on the standard for defining certain acts and measures to be taken in order to reach these standards. Then, it existed inconformity, for the presumption of certain laws would naturally lead to a certain result, but the judge, without discretion, was supposed to be responsible for the unexpected consequences of applying this law, that was unreasonable. Secondly, the court procedure was designed to protect the dignity of laws and status of local officers representing the emperor. In comparison, other parties at court seemed trivial, and thus the trial focused on accusation. Once the trial had started, punishment would be inevitable, "plaintiff«, »defendant «, "witness" might all be punished. Even the judges were not exempted of risks, especially if they applied the wrong laws or made certain ritual mistakes, which would result in degradation and blame. Thirdly, administrative officers were entitled to apply laws, which was a major defect in the Chinese legal system. Like local militia, tribunal was part of the system of protecting social norms. Efficiency for local governments, functioning of laws. Conversely, the legal system would not work, and law itself would decay. Finally, the purpose of Chinese laws was clear, it was taking responsibility for crimes, even if those crimes were a mere accident. The carrying out of punishment was »better late than never « and it was acted so as to be a deterrent to others. The righteous part of it was that bad people would receive punishment, sooner or later. Ancient Chinese criminal law seemed to assert that during the course of finding someone responsible for this crime, through investigation, the truth would be found out one day, definitely. ${ }^{67}$

When I was reading these perspectives from these British Scholars, my understanding about the authors of The Chinese Repository was deepened. I knew why they were so obsessed with the uncertainty and the abuse of punishment of Chinese law so. Western Case Law traditions, judges' power to interpret and to make laws, and Western justice views (which were different from Chinese orderoriented values), all contributed to »barbarity and cruelty« of ancient Chinese laws in Westerners' minds. ${ }^{68}$
66 Buxbaum (1971), quoted from You Chenjun (2009) 476.

67 See Van der Sprenkel (2000) 79-87. Sprenkel's perspectives were also quoted by two American professors: BODDE/MOrRIS (2003) 18-19 and 34.
68 It is noticeable that when we compare discrepancies between Chinese and Western legal traditions, we cannot isolate their geographical disparities. Professor WANG ZHIQIANG (2008) said, from the mid $18^{\text {th }}$ to the mid $19^{\text {th }}$ century, though Chinese statue law and British case law differed in the technical deduction, they shared similarities in influence and the manner of dissemination, and it serves as a warning when we are considering these questions. Hereby, I would like to thank Professor Arnd 


\section{Conclusion}

The Chinese Repository, though not the only media for Sino-West communication, was a major propagation medium at that time. With its massive publications and influence of its authors and editors in education and religion, The Chinese Repository had a huge influence. Moreover, as the earliest American work on Sinology, it was not only the basic reference for sinologists in $19^{\text {th }}$ century, but also is quoted by scholars today. In modern times, especially for the Westerners after $19^{\text {th }}$ century, the Chinese criminal law in their minds had a great deal to do with The Chinese Repository. And their minds, to some degree, caused their promotion of consular jurisdiction ${ }^{69}$ in the treaties born out of the two Opium Wars, and their policies to China afterwards.

In Memorials of Protestant Missionaries to the Chinese: Giving a List of Their Publications and Obituary Notices of the Deceased, Mr. Zhou Zhenhe mentioned that after late Ming Dynasty, there were three types of people coming to China: missionaries, merchants and diplomats. After the late Qing Dynasty, merchants and diplomats were more active in their businesses, while missionaries were more open and deep-minded, and their influence went far beyond the former two groups. For outstanding missionaries, their feats lay in their contributions to Sino-West communications or rela- tions rather than preaching, and even sometimes it needed to be proven whether their contributions were good nor not. The way that The Chinese Repository was used by Bridgman and S.W. Williams to introduce Chinese criminal views could be the best example of it.

In addition, China's image went from a »civilized and bright empire « by Voltaire to a »empire immobile in the mid $19^{\text {th }}$ century, while the West's transformation was that of »barbarians « to the imagining »Utopia«. When the unequal treaty was signed, the shift of status even indirectly influenced the forerunners and intellectuals advocating revolution in the Westernization Movement. Their judgments on the Chinese and Western criminal laws might be affected by the spread of the Chinese criminal law mindset and shaped by The Chinese Repository. Scholars in the late Qing Dynasty admitted »comparing Chinese law with other countries«, and we can observe the essence of such thinking in our own, but their criminal systems were not in accordance with their Chinese counterpart, and the degree of crimes differed as well. In general, Chinese punishment is heavier than western « ${ }^{70}$ It is understandable why some people would link these scholars' views with The Chinese Repository.

\section{Bibliography}

- Blue, Gregory (2005), China and the Modern Western Society Thoughts (translated by Song Jiafu), in: China and Historical Capitalism, edited by Timothy Brook and Gregory Blue, Beijing: Xin Xing Publishing House, 71-131

- Bodde, Derke, Clarence Morris (2003), Law in Imperial China (translated by Zhu Yong), Nanjing: Jiangsu People's Publishing

- Bourgon, Jérôme (2006), Comparison between visualization Chinese Extreme Punishment and Its European Counterparts (translated by Chen Shuliang), http://turandot.Ish-lyon.cnrs.fr/Essay.php?ID=43

- Buxbaum, David C. (1971), Some Aspects of Civil Procedure and Practice at the Trial Level in Tanshui and Hsinchu from 1789 to 1895, in: The Journal of Asian Studies 30,2 (1971) 255-279

Helmut Hafner, a German sinologist who is living in Japan now. On 18 March 2010, he gave a lecture at the East China University of Political Science and Law; what he said and his reply to my question enlightened me when I was writing this paper.

69 For background information, see LI XIUQING (2010a). In addition, after the signature of the Treaty of Wanghia, American Minister Caleb Cushing (1800-1879), reported the part of consular jurisdiction to the American government, his general idea was: China was not the member of "Christian Countries Family«, so the Western criminals could not be handed to China. He was trying to express that as a "pagan " country, Chinese criminal law was barbarian and ruthless, and it would not treat Christians fairly. His idea was the same as the one found in The Chinese Repository. As for Cushing's theory, see Li Dingyi (1997) 110-113. 70 Shen Jiaben, Ji Yi Wen Cun, Index 1. 
- Contact and Confrontation. Chinese Legal Systems in the eyes of Westerners since $16^{\text {th }}$ century, Beijing: Peking University Press (2007)

- Dennett, Tyler (1959), Americans in Eastern Asia (translated by Yao Cengyi), Beijing: The Commercial Press

- Foucault, Michel (2007), Surveiller et Punir (translated by Liu Beicheng, Yang Yuanying), Beijing: SDX Joint Publishing Company

- Gu Jun, Yang Huiling (eds.) (2008), List of Articles and Subject Index of Chinese Repository, Guilin: Guangxi Normal University Press

- Hao Ping, Zhang Xiping (2009), Establish Cultural Consciousness and Promote International Sinology Study, in: Gu Jun, Samuel W. Williams and the early American Sinology, Beijing: Foreign Language Teaching and Research Press

- Hunter, William C. (2003), Bits of Old China (translated by Shen Zhenbang and revised by Zhang Wenqin), Taipei: Taiwan Ancient Books Publishing Co.

- Latourette, Kenneth Scott (1963), The History of Early Relations Between the United States and China, 1784-1844 (translated by Chen Yu), Beijing: Commercial Press

- Lazich, Michael C. (2008), Qianxinian de Ganzhao (translated by Yin Wenjuan), Guilin: Guangxi Normal University Press

- Li DingYi (1997), Early Diplomatic Relations between China and US, Beijing: Peking University Press

- Li Xiuqing (2010a), Historical Investigation of Early Conflicts between Chinese and US Laws based on the case of Francis Terranova in 1821, in: Peking University Law Journal 3 (2010) 425-438

- Li Xiuging (2010b), The Chinese Repository and the Study on the China and West legal Culture Exchange History, in: Journal of China University of Political Science and Law No. 4 (2010) 149-157

- Liu He (2009), Imperial Discourse Politics. The Formation of the Modern World Order from Chinese and Western Conflicts (translated by Yang Lixin), Beijing: SDX Joint Publishing Company

- Memorials of Protestant Missionaries to the Chinese. Giving a List of Their Publications, on The Indo-Chinese Gleaner, in: Qiluxuekan 5 (2002) 40-46

- Miller, William (1801), The Punishments of China. Illustrated by Twenty-two Engravings, London

- Morrison, Elizabeth (2004), Memoirs of The Life and Labours of Robert Morrison (translated by Gu Changsheng), Guilin: Guangxi Normal University Press

- Qiu Huafei (2006), E. C. Bridgman and The Chinese Repository, in: Historical Archives 3 (2006) 46-50

- Quan Shichao, Daoyuan Zhang (2009), Compile of Debating Cases, Beijing: Law Press

- Smith, George (2007), The Narrative of the Exploratory Visit to Each of the Consular Cities of China (translated by Wen Shixin), Beijing: Beijing Library Press

- Shen Jiaben, Delete Heavy Punishment in Ta Tsing Leuh-le, Ji Yi Wen Cun, Index 1

- Staunton, G.T. (1810), Ta Tsing Leu Lee, Being the Fundamental Laws and a Selection from the Supplementary Statutes of the Penal Code of China, London

- Staunton, G.T. (1997), An Authentic Account of An Embassy from the Kingdom of Great Britain to the Emperor of China (translated by Ye Duyi), Shanghai: Shanghai Publishing Press

- Tan Shulin (2008), Interpretation of The Chinese Repository, in: Historical Archives No. 3 (2008) 84-89

- Tian Tao, Zheng Qin (1999), Qing Legal Code, Beijing: Law Press

- Van der Sprenkel, Sybille (2000), Legal Institutions in Manchu China. A Sociological Analysis (translated by Zhang Shoudong), Beijing: China University of Political Science and Law Press

- Wang Zhiqiang (2008), The Comparison between Chinese and British Precedent System, in: Chinese Journal of Law 3 (2008) 114-125

- Williams, Frederick Wells (2004), The Life and Letters of Samuel Wells Williams (translated by Gu Jun, Jiang Li), Guilin: Guangxi Normal University Press

- Wu Yixiong (2008a), The Chinese Repository and the Study of Chinese History, in: Journal of Zhongshan University. Social and Science Edition 1 (2008) 79-91

- Wu Yixiong (2008b), The Chinese Repository and Chinese Language Study, in: Social and Science Research No. 4 (2008) 137-144

- Wu Yixiong (2009), The Chinese Repository and Its Study on Chinese Social Belief and Customs, in: The Academic Research No. 9 (2009) 101-113

- Xu Lian, Xiong E (2009), The Plus or Minus of Punishment by the Ministry of Punishments in Feudal China, Beijing: Law Press

- Ye Nong (2002), Study on the Introduction of Protestant Missionaries and Western Medicine Surgery. The Analysis of The Chinese Repository, in: Guangdong Chronicles No. 3 (2002) 36-43

- Yin Wenjuan (2005), The Society of Jesus and the Excerpt from the Qing Government Gazette by the Protestant Missionaries, in: World Religion Research 2 (2005) 71-82

- You Chenjun (2009), How Might a »New Legal History« Be Possible. Recent Trends of Chinese Legal History Studies in the United States and Its Implications, in: Huang Zongzhi, You Chenjun (2009), Research from Archival Case Records. Law, Society and Culture in China, Beijing: Law Press 